\title{
Employment, Consumption, Debt, and European Industrial Relations Systems
}

\author{
COLIN CROUCH*
}

\begin{abstract}
Comparisons between British and German employment performance in recent years have characterized the two countries as, respectively, finding a formula of high employment based on high-consumption expenditure financed by household debt, and remaining tied to an external trade and low-consumption model that no longer creates jobs. Placing these two countries in a wider perspective of all European Union member states and the United States reveals a different picture. Two different patterns seem associated with high employment levels: a northern European one of low-consumption expenditure and high household debt, and an Anglophone one of high-consumption expenditure and high household debt. Links for these contrasting models are sought in their very different social policy and industrial relations systems. Questions are raised concerning the role of household debt in the northern European cases, and the lack of any clear patterns differentiating much of western, southern and central Europe.
\end{abstract}

\section{Introduction}

THE FINANCIAL CRISIS OF 2008-2009 DEMONSTRATED THE IMPORTANCE IN SEVERAL economies of high levels of household debt to provide resources in which secondary financial markets could trade. Attention has obviously been paid to the consequences for the banking system and public finances, but there are also implications for other parts of society. Ideas of distinctive societal models and varieties of capitalism (Amable 2003; Crouch and Streeck 1997; EspingAndersen 1990, 1999; Hall and Soskice 2001) have drawn attention to the interconnectedness of institutions, linking financial systems, industrial relations arrangements, and social policy. In particular, an identifiable Anglophone form of capitalism has been depicted as characterized by highly flexible, unregulated, and short-termist financial markets. For many observers, these characteristics have been a strength and key to the perceived economic success since the mid-1990s of the countries involved, and as having important implications for how labor markets have been governed. This narrative has to

\footnotetext{
* The author's affiliation is Professor emeritus, University of Warwick Business School, Coventry, UK E-mail: colin.crouch@wbs.ac.uk.

Industrial Relations, Vol. 51, No. S1 (April 2012). (C) 2012 Regents of the University of California Published by Wiley Periodicals, Inc., 350 Main Street, Malden, MA 02148, USA, and 9600 Garsington Road, Oxford, OX4 2DQ, UK.
} 


\section{0 / Colin Crouch}

be re-evaluated in the light of the crisis of that system, although the way in which its earlier success led to its being imitated in many other societies weakens the force of the contrasts that might be observed with other system types.

One achievement of the literature on varieties of capitalism has been to challenge the separations that used to exist among different objects of social research. A generation ago, industrial relations specialists would rarely have mentioned the financial system as a relevant variable; they would not often have even mentioned other fields of social policy, as their nineteenth- and early-twentieth-century predecessors certainly did. This is no longer defensible, and we need to be aware of the interconnectedness of institutional spheres, and how our principal object of study is affected by its environing institutions.

On the eve of the financial crisis, one could very roughly summarize the achievements of a more integrative literature as follows:

1. The neo-liberal Anglophone economies, with liberalized finance, residual social policy, flexible labor markets, and rather weak industrial relations institutions were seen as achieving high levels of economic success, as measured by rates of growth, innovative capacity, and levels of employment. They did not perform very well in international trade in manufacturing, but had developed an endogenous growth model, the population creating employment by buying and selling flexibly produced services to each other. The international trade deficits did not matter, because foreigners were willing to buy the debt, taking advantage of the lightly regulated financial system.

2. In the Nordic countries, a combination of economic liberalization with highly advanced social policy, mixed labor markets, and very powerful industrial relations institutions were achieving similar levels of innovative capacity and employment levels, with overall lower growth rates but also with less inequality and poverty. Employment was sustained mainly by high levels of public spending.

3. Germany and Austria (and to some extent Japan) had less liberalized economies, advanced but inegalitarian social policy, rigid labor markets, and strong industrial relations institutions protecting trade unions that were in reality weak. These features were associated with continuing strong performance in manufacturing and international trade, as strong labor institutions with relatively weak unions kept wages under control. Rigidities, however, prevented growth in services employment, so both economic growth and in particular employment levels were weak. 
4. The remaining countries of the industrial world-primarily those in southwest Europe-lacked liberalization in all aspects of their economies, as well as poorly developed social policy, and lacked the accumulated manufacturing strength favored by German institutions. Their economies therefore lacked innovation and growth and produced poor levels of employment.

There are unresolved problems with this account. No place is found for France; the countries of central and eastern Europe are largely ignored; important differences among countries within the groupings are glossed over. However, these accounts give us some preliminary groupings of countries, some guide to how various institutions might hang together, and ideas for relevant dependent and independent variables. They also present an account of these institutions before the crisis. A fundamental fact revealed by the crisis was that the Anglo-American economies had become dependent on unsustainable levels of household debt among workers on moderate incomes to maintain their growth model (Bellofiore and Halevi 2012; Crouch 2009; Panitch and Konings 2009; Wade 2008). This suggested that the deregulated finance system had been associated with economic success, through any role it played not only in improving economic efficiency, but in enabling workers with insecure jobs and static real wages to keep spending.

The present article explores how the accounts we give of different types of economy need to change in the light of that crisis, with particular reference to different kinds of industrial relations systems. Eventually, research of this kind is capable of econometric testing and a search for causal links. Initially however it is valuable to explore potential relationships in a less formal way, examining descriptive statistics for a set of cases in a way that enables us to think further about the characteristics of individual instances. A principal aim of this article is therefore to stimulate further inquiry. For that reason, it raises far more questions than it resolves.

\section{Taking Stock after the Crisis}

The key economic variables that we have discussed are external trade balance, private consumption, government consumption, household debt, and employment. Then come certain institutional variables concerning social policy and industrial relations. We shall consider data for all European Union member states along with the United States, and across a period of years, as indicators change over a period. 


\section{2 / Colin Crouch}

When expressed as a proportion of gross domestic product (GDP), external trade balance, plus private and government consumption, plus gross fixed capital formation and some additional small items are necessarily equal to GDP. We shall therefore first concentrate on one of these items, private consumption, turning at a later stage to inspect differences in the relative weights of government consumption and trade balance in particular cases. Consideration of the institutional variables will follow. As has been argued earlier, household debt is expected to play a role in supporting private consumption.

The basic hypothesis is that the employment level in a national economy will be some function of the share of private consumption in GDP and the level of household debt, or:

$$
\mathrm{E}=\int(\mathrm{C}, \mathrm{D}),
$$

where $\mathrm{E}=$ the proportion of the population of working-age population in employment, $\mathrm{C}=$ private final consumption as a percentage of GDP, and $\mathrm{D}=$ private household debt as a percentage of personal income.

It is further expected, on the basis of comparisons between the Anglophone and "German" types of economy, that $\mathrm{E}$ will vary directly with $\mathrm{C}$ and that $\mathrm{C}$ will vary directly with $\mathrm{D}$.

The hypotheses do not specify any causal relationships; these remain to be explored if any substance is found in the presumed association. Hypotheses of this kind are testable across a range of countries and years, but it is a further assumption of this paper that any association will not be a straightforward statistical one between the specified economic variables, but one that also requires taking account of structural, institutional variables. This questions the legitimacy of regarding separate annual observations within individual countries as observations of totally separate cases, as institutional variables change only slowly. In addition, this research is taking place at an initial exploratory stage, where we are seeking possible relationships that might be tested systematically later. Statistical operations will therefore be kept at a simple level, enabling us to examine individual national examples, and groups of these, in order to search for further hypotheses for later exploration with richer data.

Data will be taken from all European Economic Area states for which the relevant statistics are collected on a comparable basis by Eurostat, less countries with populations of under one million, as very small countries are likely to have economies skewed toward particular activities and sectors. The United States will be related to this scheme where possible, but unfortunately Eurostat does not report comparable statistics on household debt for that country. The data will be examined at two points: in 2000, when the U.S. and UK 
asset-based economies were at their height, and in 2009, immediately after the financial crisis.

Table 1 reports the basic data, and Table 2 the simple statistical relationships. These are calculated using the European cases only. Contrary to our initial hypothesis, the share of private consumption in GDP correlates negatively, albeit weakly, with household debt levels, especially in the earlier period. Private consumption also correlates negatively with employment levels, again particularly in the earlier period. The level of household debt does correlate positively and fairly strongly with employment, but it clearly does not pass through a route that relates debt to employment via private consumption.

\section{TABLE 1}

Employment, Consumer Spending, and Household Debt in European Countries and the United States, 2000 and 2008/2009

\begin{tabular}{|c|c|c|c|c|c|c|}
\hline \multirow[b]{2}{*}{ Country } & \multicolumn{3}{|c|}{2000} & \multicolumn{3}{|c|}{$2008 / 2009$} \\
\hline & $\mathrm{E}$ & $\mathrm{C}$ & $\mathrm{D}$ & $\mathrm{E}$ & $\mathrm{C}$ & $\mathrm{D}$ \\
\hline Austria & 68.50 & 54.83 & 73.89 & 71.60 & 54.58 & 82.42 \\
\hline Belgium & 60.50 & 53.28 & 62.15 & 61.60 & 52.11 & 79.21 \\
\hline Bulgaria & 50.40 & 69.17 & 18.00 & 62.60 & 65.41 & 45.20 \\
\hline Czech Republic & 65.00 & 52.50 & 13.02 & 65.40 & 50.64 & 37.16 \\
\hline Denmark & 76.30 & 47.66 & 184.00 & 75.70 & 49.25 & 265.72 \\
\hline Estonia & 60.40 & 55.46 & 15.25 & 63.50 & 52.94 & 87.89 \\
\hline Finland & 67.20 & 47.93 & 60.84 & 66.70 & 55.26 & 97.96 \\
\hline France & 62.10 & 55.73 & 55.32 & 64.20 & 58.35 & 75.28 \\
\hline Germany & 65.60 & 58.87 & 104.94 & 70.90 & 57.34 & 89.44 \\
\hline Greece & 56.50 & 72.37 & 17.06 & 61.20 & 72.57 & 70.70 \\
\hline Hungary & 56.30 & 53.00 & 9.43 & 55.40 & 53.06 & 61.79 \\
\hline Ireland & 65.20 & 48.55 & 107.00 & 61.80 & 49.50 & 196.69 \\
\hline Italy & 53.70 & 59.92 & 31.95 & 57.50 & 59.93 & 56.57 \\
\hline Latvia & 57.50 & 62.53 & 8.55 & 60.90 & 60.89 & 73.21 \\
\hline Lithuania & 59.10 & 64.62 & 2.21 & 60.10 & 68.40 & 45.28 \\
\hline The Netherlands & 72.90 & 50.44 & 151.83 & 77.00 & 46.34 & 227.94 \\
\hline Norway & 77.50 & 43.21 & 118.51 & 76.40 & 42.03 & 180.06 \\
\hline Poland & 55.00 & 64.13 & 9.77 & 59.30 & 61.44 & 49.42 \\
\hline Portugal & 68.40 & 63.88 & 87.18 & 66.30 & 65.82 & 134.90 \\
\hline Romania & 63.00 & 68.47 & 1.47 & 58.60 & 62.75 & 32.84 \\
\hline Slovakia & 56.80 & 56.33 & 9.49 & 60.20 & 60.49 & 46.36 \\
\hline Slovenia & 62.80 & 57.41 & 23.35 & 67.50 & 54.80 & 41.42 \\
\hline Spain & 56.30 & 59.66 & 68.84 & 59.80 & 56.01 & 127.82 \\
\hline Sweden & 73.00 & 49.16 & 94.68 & 72.20 & 48.77 & 137.22 \\
\hline Switzerland & 78.30 & 59.87 & 155.81 & 79.20 & 58.17 & 169.63 \\
\hline UK & 71.20 & 65.55 & 100.38 & 69.90 & 65.23 & 152.62 \\
\hline United States & 74.10 & 68.64 & n.a. & 70.90 & 70.77 & n.a. \\
\hline
\end{tabular}

SOURCE: Eurostat statistical data base; author's calculations.

$\mathrm{E}=$ Percentage of population aged 15 to 64 in some kind of paid employment (2000 and 2009).

$\mathrm{C}=$ Percentage share in gross domestic product of private final consumption expenditure (2000 and 2009).

$\mathrm{D}=$ Household debt as a percentage of net national disposable income (2000 and 2008). 
TABLE 2

Statistical Relationships Among the Variables in Table 1 (European Countries Only)

\begin{tabular}{llllllll}
\hline \hline & \multicolumn{3}{c}{2000} & & & \multicolumn{2}{c}{2009} \\
\cline { 2 - 3 } \cline { 7 - 8 } & \multicolumn{1}{c}{$\mathrm{C}: \mathrm{E}$} & $\mathrm{D}: \mathrm{E}$ & $\mathrm{C}: \mathrm{D}$ & & $\mathrm{C}: \mathrm{E}$ & $\mathrm{D}: \mathrm{E}$ & $\mathrm{C}: \mathrm{D}$ \\
\hline$r$ & -0.5376 & 0.8283 & -0.4893 & & -0.4659 & 0.6969 & -0.5066 \\
$S D$ & 8.18 & 37.32 & 37.84 & & 8.14 & 48.32 & 50.19 \\
\hline
\end{tabular}

Simple correlations cannot reveal non-linear complexities in relationships among variables. Table 3 enables us to examine some of these by relating all three variables, indicating for each those countries where values were, respectively, more than half and more than one standard deviation above or below the mean. These values are calculated using the European cases only, but the United States is also related to the findings. Looking first at 2000, we see that the highest employment levels (those marked $\mathrm{V}$, indicating levels of more than one standard deviation above the mean) were also strongly associated with high levels of household debt (level IV or V), in that no country with relatively high employment levels failed also to have relatively high debt (the Scandinavian countries, the Netherlands, Switzerland, and the UK). We can also be confident that the United States would come within this category, were we to have comparable data on its debt. One country, Portugal, with the second level of employment (IV) also came in that category for debt; the other, Austria, had only modest debt levels. Only one country combined high debt with a relatively modest (III) employment level: Germany. The only country with high employment but relatively modest debt was Austria. The three countries with the lowest employment levels (I) also had very low (I-Bulgaria and Poland) or fairly low (II-Italy) levels of debt. Countries at level II for employment also had very low (I) levels of debt: Greece, Hungary, Latvia, Lithuania, Slovakia. The only exception was Spain, which had moderate (III) debt.

Employment levels were not being sustained in a straightforward way by consumer spending financed by debt. Of the countries that combined high employment and high debt, only the UK (and probably the United States) combined high consumption with these elements. In general, countries with high levels of private consumption had both low debt and low employment levels: Bulgaria, Greece, Latvia, Lithuania, and Poland. Portugal is the only exception. Switzerland is an intermediate case between these two groups. Apart from the UK (and probably the United States), the other countries with high or very high private consumption levels mainly had low or very low levels of employment. 
TABLE 3

Relative Performance on Employment, Consumer Spending, and Household Debt in European Countries and the United States, 2000 and 2008/2009

\begin{tabular}{|c|c|c|c|c|c|c|}
\hline \multirow[b]{2}{*}{ Country } & \multicolumn{3}{|c|}{2000} & \multicolumn{3}{|c|}{2009} \\
\hline & $\mathrm{E}$ & $\mathrm{C}$ & D & $\mathrm{E}$ & $\mathrm{C}$ & D \\
\hline Austria & IV & III & III & IV & III & III \\
\hline Belgium & III & II & III & II & II & II \\
\hline Bulgaria & I & V & I & III & $\mathrm{V}$ & I \\
\hline Czech Republic & III & II & I & III & II & I \\
\hline Denmark & $\mathrm{V}$ & I & $\mathrm{V}$ & $\mathrm{V}$ & I & V \\
\hline Estonia & III & III & I & III & II & III \\
\hline Finland & III & I & III & III & III & III \\
\hline France & III & III & III & III & III & II \\
\hline Germany & III & III & $\mathrm{V}$ & IV & III & III \\
\hline Greece & II & V & I & II & $\mathrm{V}$ & II \\
\hline Hungary & II & II & I & I & II & II \\
\hline Ireland & III & I & III & II & I & V \\
\hline Italy & I & III & II & I & II & II \\
\hline Latvia & II & IV & I & II & IV & II \\
\hline Lithuania & II & IV & I & II & IV & II \\
\hline The Netherlands & $\mathrm{V}$ & II & $\mathrm{V}$ & $\mathrm{V}$ & I & $\mathrm{V}$ \\
\hline Norway & $\mathrm{V}$ & I & V & $\mathrm{V}$ & I & V \\
\hline Poland & I & IV & I & II & IV & II \\
\hline Portugal & IV & IV & IV & III & $\mathrm{V}$ & IV \\
\hline Romania & III & $\mathrm{V}$ & I & I & IV & I \\
\hline Slovakia & II & III & I & II & IV & II \\
\hline Slovenia & III & III & II & III & III & II \\
\hline Spain & II & II & III & I & III & IV \\
\hline Sweden & $\mathrm{V}$ & I & IV & $\mathrm{V}$ & I & IV \\
\hline Switzerland & $\mathrm{V}$ & III & V & $\mathrm{V}$ & III & V \\
\hline UK & $\mathrm{V}$ & $\mathrm{V}$ & V & IV & $\mathrm{V}$ & IV \\
\hline United States & $\mathrm{V}$ & V & n.a. & IV & $\mathrm{V}$ & n.a. \\
\hline
\end{tabular}

For abbreviations, see Table 1 .

$\mathrm{V}=>+1 S D$ (standard deviation).

$\mathrm{IV}=>0.5$ to $+1 S D$.

III $=>-0.5$ to $+0.5 S D$.

II $=-1$ to $-0.5 S D$.

$\mathrm{I}=<-1 S D$.

The main overall change that took place by $2008 / 2009$ was the doubling of household debt from a national mean of 60.96 percent of disposable income in 2000 to 102.50 percent in 2008. The 2000s were the decade when high household debt became a major feature of the world's most advanced economies. The mean for consumption share was static (moving from 57.48 percent of GDP to 57.00 percent in 2009), while employment rose slightly from 63.88 percent to 65.60 percent in 2009 . There are only minor changes in the relative positions of countries. Among the high-employment performers, Germany rises from III to IV and the UK declines from V to IV (as does the United States). 


\section{6 / Colin Crouch}

Although debt rises overall, the only major relative changes are in Estonia's position from I to III, Ireland's from III to $\mathrm{V}$, and the opposite move from $\mathrm{V}$ to III for Germany.

All countries with relatively very high employment (V) combine high debt with low rates of private final consumption (Denmark, the Netherlands, Norway, Sweden), with the exception of Switzerland, which has moderate (III) consumption levels. Countries with high employment (IV) either have moderate scores (III) on both consumption and debt indicators (Austria and Germany, probably Japan), or combine very high consumption with high debt (the UK, probably the United States).

As noted previously, the share of private consumption in a country's GDP varies primarily with different levels of government final expenditure and trade balances. Tables 4 and 5 present, respectively, the performance of the various countries on these two items, and their relative performance on each of these constituents of GDP alongside that for private final consumption on the same basis as Table 3. In 2000, all countries that combined high- or very highemployment performance with low private consumption had both high levels of government final spending and strong balances of payments. There is a partial exception in the case of Norway, where trade balances were particularly high because of oil revenues. The other two countries with particularly strong foreign balances but moderate (Finland) or very low (Ireland) government spending levels had not featured strong employment performances. No European country combined high employment, high private consumption, and low government consumption, but the United States did present such a pattern. The UK and the United States were the only countries to combine weak performances on foreign trade with very strong employment.

By 2009, little had changed in this pattern. All countries that combined high or very high-employment performance with low private consumption had very high levels of government final spending and strong or moderate balances of payments (Denmark, the Netherlands, Sweden), with the partial exception again of Norway. A group of countries with high or very high employment and moderate consumption (Austria, Germany, Switzerland) presented no particular profile; only Germany had a strong balance of payments performance, although none were weak on this variable. Both countries that combined high employment with high private consumption (the UK and the United States) had poor balance of payments records, but they had different profiles on government final consumption.

Certain patterns of countries appear in these statistical narratives, and they bear at least some relationship to how the literature on varieties of capitalism groups them: the UK and the United States share important characteristics; so do the Scandinavian countries. But these two groups also share certain 
TABLE 4

Government Spending and External Trade Balance in European Countries and the United STATES, 2000 AND 2009

\begin{tabular}{lccccc}
\hline \hline & \multicolumn{2}{c}{2000} & & \multicolumn{2}{c}{2009} \\
\cline { 2 - 3 } \cline { 5 - 5 } Country & $\mathrm{G}$ & $\mathrm{B}$ & & $\mathrm{G}$ & $\mathrm{B}$ \\
\hline Austria & 19.1 & -2.44 & 19.9 & -1.50 \\
Belgium & 21.3 & 4.66 & 24.6 & 3.80 \\
Bulgaria & 17.9 & -13.37 & 16.1 & -14.58 \\
Czech Republic & 21.1 & -5.07 & 22.1 & 4.33 \\
Denmark & 25.1 & 3.58 & 29.7 & 3.38 \\
Estonia & 19.8 & -18.96 & 22.2 & -5.94 \\
Finland & 20.5 & 9.56 & 25.1 & 0.96 \\
France & 22.9 & -0.85 & 24.6 & -2.86 \\
Germany & 19.0 & 2.87 & 19.7 & 5.50 \\
Greece & 17.8 & -17.06 & 19.0 & -12.00 \\
Hungary & 21.2 & -8.39 & 21.5 & 4.30 \\
Ireland & 13.6 & 27.24 & 19.2 & 22.90 \\
Italy & 18.4 & 0.16 & 21.6 & -0.27 \\
Latvia & 20.8 & -16.99 & 21.1 & -7.63 \\
Lithuania & 22.8 & -14.75 & 21.7 & -4.80 \\
The Netherlands & 22.0 & 3.85 & 28.2 & 6.65 \\
Norway & 19.3 & 14.46 & 22.2 & 13.50 \\
Poland & 17.4 & -10.08 & 18.3 & -2.81 \\
Portugal & 19.3 & -13.80 & 22.7 & -11.59 \\
Romania & 17.5 & -7.29 & 18.1 & -8.44 \\
Slovakia & 20.2 & -4.56 & 19.6 & 0.86 \\
Slovenia & 18.8 & -6.96 & 20.2 & -0.44 \\
Spain & 17.2 & -7.02 & 21.2 & -4.71 \\
Sweden & 26.3 & 5.75 & 27.7 & 2.93 \\
Switzerland & 11.1 & -0.80 & 11.3 & 3.47 \\
UK & 18.6 & -4.23 & 23.5 & -5.91 \\
United States & 14.3 & -4.80 & 17.0 & -5.75 \\
\hline Sowre & & & &
\end{tabular}

SOURCE: Eurostat statistical base.

$\mathrm{G}=$ Percentage share in gross domestic product (GDP) of government final consumption expenditure (2000 and 2009 ).

$\mathrm{B}=$ Balance of external trade as percentage of GDPt (2000 and 2009).

similarities. To inquire further, we need to present these patterns more systematically, simplifying by concentrating on patterns emerging from research on industrial relations systems.

\section{Employment, Consumption, and Industrial Relations Systems}

The most recent formulation of country groupings in this field is to be found in the European Commission's report on industrial relations in Europe in 2008 (European Commission 2008). This is based on a number of studies of comparative European industrial relations and welfare states (Crouch 1993, 1996; 
TABLE 5

Relative Performance on Consumer Spending, Government Spending, and External Trade Balance in European Countries and the United States

\begin{tabular}{|c|c|c|c|c|c|c|}
\hline \multirow[b]{2}{*}{ Country } & \multicolumn{3}{|c|}{2000} & \multicolumn{3}{|c|}{2009} \\
\hline & $\mathrm{C}$ & G & $\mathrm{B}$ & $\mathrm{C}$ & G & B \\
\hline Austria & III & III & III & III & III & III \\
\hline Belgium & II & IV & IV & II & IV & IV \\
\hline Bulgaria & $\mathrm{V}$ & II & II & $\mathrm{V}$ & I & I \\
\hline Czech Republic & II & III & III & II & III & IV \\
\hline Denmark & I & $\mathrm{V}$ & IV & I & $\mathrm{V}$ & III \\
\hline Estonia & III & III & I & II & III & II \\
\hline Finland & I & III & $\mathrm{V}$ & III & IV & III \\
\hline France & III & $\mathrm{V}$ & III & III & IV & III \\
\hline Germany & III & III & IV & III & III & IV \\
\hline Greece & $\mathrm{V}$ & II & I & $\mathrm{V}$ & II & I \\
\hline Hungary & II & IV & III & II & III & IV \\
\hline Ireland & I & I & $\mathrm{V}$ & I & II & $\mathrm{V}$ \\
\hline Italy & III & III & III & II & III & III \\
\hline Latvia & IV & III & I & IV & III & I \\
\hline Lithuania & IV & $\mathrm{V}$ & I & IV & III & II \\
\hline The Netherlands & II & IV & IV & I & $\mathrm{V}$ & IV \\
\hline Norway & I & III & $\mathrm{V}$ & I & III & $\mathrm{V}$ \\
\hline Poland & IV & II & II & IV & II & III \\
\hline Portugal & IV & III & I & V & III & I \\
\hline Romania & $\mathrm{V}$ & II & III & IV & II & II \\
\hline Slovakia & III & III & III & IV & II & III \\
\hline Slovenia & III & III & III & III & III & III \\
\hline Spain & II & II & III & III & III & II \\
\hline Sweden & I & $\mathrm{V}$ & IV & I & $\mathrm{V}$ & III \\
\hline Switzerland & III & I & III & III & I & III \\
\hline UK & $\mathrm{V}$ & III & III & $\mathrm{V}$ & III & II \\
\hline Japan & III & II & III & III & III & III \\
\hline United States & $\mathrm{V}$ & I & III & $\mathrm{V}$ & I & II \\
\hline
\end{tabular}

For abbreviations see Tables 1 and 4 .

$\mathrm{V}=>+1 S D$ (standard deviation).

$\mathrm{IV}=>0.5$ to $+1 S D$.

$\mathrm{III}=>-0.5$ to $+0.5 S D$.

II $=-1$ to $-0.5 S D$.

$\mathrm{I}=<-1 S D$.

Ebbinghaus and Visser 1997; Esping-Andersen 1990; Kohl and Platzner 2007; Schmidt 2002, 2006). It identifies the following groupings:

North (the Nordic countries),

Center West (Germany and the smaller countries of northwest Europe),

South (the southern countries of the pre-enlargement European Union),

West (Ireland and the UK), and

Center East (the ex-communist EU member states). 
The EU authors make some changes to their essentially geographical scheme. They allocate Slovenia outside the Center East and put it with Center West. They also put France with South, a designation usually reserved for social policy systems that give a strong role for the family. These are justifiable switches when the focus is on industrial relations systems as they exist now, as opposed to social policy or earlier political development paths. The EU authors also express some doubt about the allocation of Finland (ambiguous between North and Center West, and Hungary (ambiguous between Center

\section{TABLE 6}

Performance on Employment, Private Consumption, and Debt Indicators According to INDUSTRIAL RELATIONS IN EUROPE 2008

\begin{tabular}{|c|c|c|c|c|c|c|c|}
\hline \multirow[b]{2}{*}{ Social policy regime } & \multirow[b]{2}{*}{ Country } & \multicolumn{3}{|c|}{2000} & \multicolumn{3}{|c|}{$2008 / 2009$} \\
\hline & & $\mathrm{E}$ & $\mathrm{C}$ & $\mathrm{D}$ & $\mathrm{E}$ & $\mathrm{C}$ & $\mathrm{D}$ \\
\hline \multirow[t]{4}{*}{ North } & Denmark & $\mathrm{V}$ & I & $\mathrm{V}$ & $\mathrm{V}$ & I & $\mathrm{V}$ \\
\hline & Finland* & III & I & III & III & III & III \\
\hline & Norway & $\mathrm{V}$ & I & $\mathrm{V}$ & $\mathrm{V}$ & I & $\mathrm{V}$ \\
\hline & Sweden & $\mathrm{V}$ & I & IV & $\mathrm{V}$ & I & IV \\
\hline \multirow[t]{6}{*}{ Center West } & Austria & IV & III & III & IV & III & III \\
\hline & Belgium & III & II & III & II & II & II \\
\hline & Germany & III & III & $\mathrm{V}$ & IV & III & III \\
\hline & the Netherlands & $\mathrm{V}$ & II & $\mathrm{V}$ & $\mathrm{V}$ & I & $\mathrm{V}$ \\
\hline & Slovenia & III & III & II & III & III & II \\
\hline & Switzerland & $\mathrm{V}$ & III & $\mathrm{V}$ & $\mathrm{V}$ & III & $\mathrm{V}$ \\
\hline \multirow[t]{5}{*}{ South } & France & III & III & III & III & III & II \\
\hline & Greece & II & $\mathrm{V}$ & I & II & $\mathrm{V}$ & II \\
\hline & Italy & I & III & II & I & II & II \\
\hline & Portugal & IV & IV & IV & III & $\mathrm{V}$ & IV \\
\hline & Spain & II & II & III & $\mathrm{I}$ & III & IV \\
\hline \multirow[t]{2}{*}{ West } & Ireland* & III & I & III & II & I & $\mathrm{V}$ \\
\hline & UK & $\mathrm{V}$ & $\mathrm{V}$ & $\mathrm{V}$ & IV & $\mathrm{V}$ & IV \\
\hline \multirow[t]{9}{*}{ Center East } & Bulgaria & I & $\mathrm{V}$ & I & III & $\mathrm{V}$ & I \\
\hline & Czech Republic & III & II & I & III & II & I \\
\hline & Estonia & III & III & $\mathrm{I}$ & III & II & III \\
\hline & Hungary* & II & II & I & $\mathrm{I}$ & II & II \\
\hline & Latvia & II & IV & $\mathrm{I}$ & II & IV & II \\
\hline & Lithuania & II & IV & I & II & IV & II \\
\hline & Poland & I & IV & I & II & IV & II \\
\hline & Romania & III & V & I & I & IV & I \\
\hline & Slovakia & II & III & I & II & IV & II \\
\hline
\end{tabular}

Source: European Commission (2008).

$\mathrm{V}=>+1 S D$ (standard deviation).

$\mathrm{IV}=>0.5$ to $+1 S D$.

III $=>-0.5$ to $+0.5 S D$.

II $=-1$ to $-0.5 S D$.

$\mathrm{I}=<-1 S D$.

*Cases where source expresses doubts over allocation to social policy regimes. 
East and South). Table 6 presents the findings of the above analysis of employment, consumption, and debt data classified according to this typology.

In 2000, there was a clear fit between the Nordic group, with Finland something of an exception, and the high employment, low private consumption, high-debt pattern. The high employment, high private consumption, high-debt pattern of the UK are not followed by Ireland, its fellow member of the West group. But if we follow the allocation of the United States to a similar pattern as the UK, as usually followed in studies that extend beyond Europe (e.g., Esping-Andersen 1990), we have a more substantial West group. With some exceptions, the countries in South and Center East are alike characterized by low employment, high consumption, and low debt. The Center West group lacks any overall character. The Netherlands belongs more with the North, while Switzerland seems partway between the North and the West. The only really clear positions therefore emerge among the high-employment countries. With the exception of Austria (which is in a combination of its own), the Netherlands, and the partway position of Switzerland, all countries with high (IV) or very high (V) employment levels fall in either the North or the West groups, assuming that the United States counts as West.

By 2009, little changes, except that within the Center West Germany joins Austria in its distinctive pattern of high employment and moderate scores (III) on private consumption and debt.

More progress in relating the above findings to analyses of different system types can be gained if we apply just one of the source materials of the EU study, that of Crouch (1993). This was based on an historical analysis of how different states shared participation in public management with organized interests, and of the ability of organized labor to gain recognition from employers. The former variable led to a division between corporatist systems (where power was shared with associations) and others. Where this was combined with excluded labor, the corporatism was authoritarian as under fascism; where labor was included there was neo-corporatism of the kind associated with various democratic European countries. Where labor was an accepted partner but without corporatism, there would be pluralist collective bargaining. Where there was neither corporatism at the state level nor labor inclusion at the industrial level, there would be contestation. This did not mean that there would be high levels of actual conflict; this would depend on whether organized labor had the power to contend its inclusion.

That study traced developments over more than a century, during which time different national systems occupied varying positions, as changes in power relations worked alongside path dependencies. By the early 1990s, when the account ended, the following positions were occupied: 


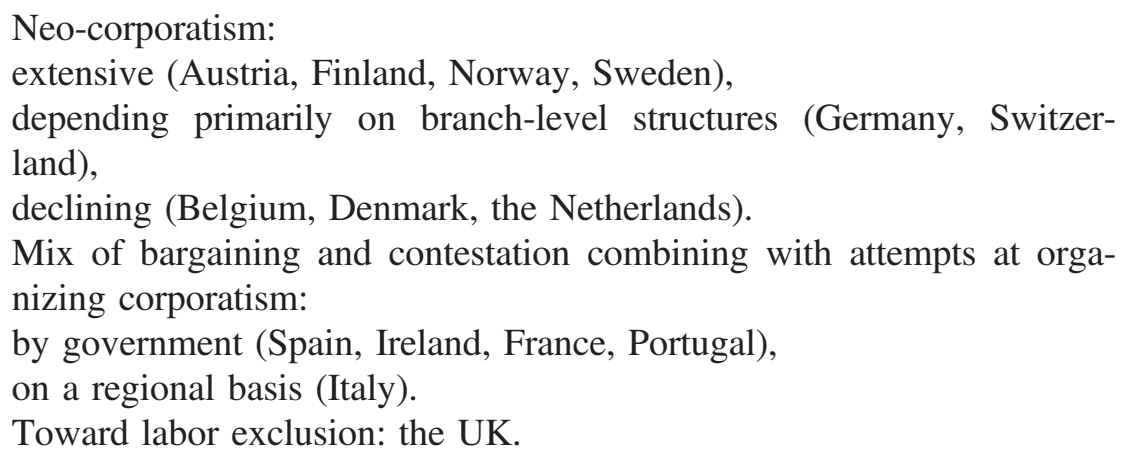

Greece was not covered in the study, but would have been added to the group "Mix of bargaining and contestation combining with attempts at organizing corporatism by government.' The study had not included the former state socialist countries.

At that historical moment, the neo-corporatist countries had for several years been regarded as the most successful in combating inflation, even if the system was weakening in some cases. Governments lacking neo-corporatist backgrounds were therefore concerned to encourage neo-corporatist arrangements. Only one country in western Europe, the UK, had struck out on a different path, toward labor exclusion at both political and, to a lesser extent, industrial levels. Outside Europe the United States was on a similar path.

These systems continued to change in different ways during the following decades. In particular, there were determined efforts to reconstruct consensus tripartite approaches to labor issues in Denmark and the Netherlands, and to construct them in Ireland. Elsewhere the attempts at constructing neo-corporatism by governments and others failed to deliver significant results except very temporarily in Italy. Gradually, these attempts were abandoned as governments and employers saw certain kinds of success in the British and U.S. neo-liberal experiments, and as globalization undermined the role of national business associations. Governments and employers in some of the neo-corporatist countries also began to imitate the Anglo-American approach, but the legacy of their earlier neo-corporatist base has rarely been completely lost.

Table 7 allocates the evidence surveyed here to the three broad categories underlying Crouch's 1993 analysis, adding the central European countries to a separate, residual category. Among the neo-corporatist countries, only Belgium, Finland, and Germany (2000 only) had employment levels below IV, and only Belgium (2009 only) had a level below III. Most members of this group also had low private consumption levels, except Austria, Germany, Switzerland, and Finland (2009 only), none of these exceptions rising above III. They all have high debt levels except for Austria, Belgium, Finland, and 
TABLE 7

Performance on Employment, Private Consumption, and Debt Indicators According to Different Industrial Relations Systems Types

\begin{tabular}{|c|c|c|c|c|c|c|c|}
\hline \multirow{2}{*}{$\begin{array}{l}\text { Industrial relations } \\
\text { system type (1990) }\end{array}$} & \multirow[b]{2}{*}{ Country } & \multicolumn{3}{|c|}{2000} & \multicolumn{3}{|c|}{2009} \\
\hline & & $\mathrm{E}$ & $\mathrm{C}$ & $\mathrm{D}$ & $\mathrm{E}$ & $\mathrm{C}$ & $\mathrm{D}$ \\
\hline \multirow[t]{9}{*}{ Neo-corporatist } & Austria & IV & III & III & IV & III & III \\
\hline & Belgium & III & II & III & II & II & II \\
\hline & Denmark & $\mathrm{V}$ & I & V & $\mathrm{V}$ & I & $\mathrm{V}$ \\
\hline & Finland & III & I & III & III & III & III \\
\hline & Germany & III & III & $\mathrm{V}$ & IV & III & III \\
\hline & The Netherlands & $\mathrm{V}$ & II & $\mathrm{V}$ & $\mathrm{V}$ & I & $\mathrm{V}$ \\
\hline & Norway & $\mathrm{V}$ & I & $\mathrm{V}$ & $\mathrm{V}$ & I & $\mathrm{V}$ \\
\hline & Sweden & $\mathrm{V}$ & I & IV & $\mathrm{V}$ & I & IV \\
\hline & Switzerland & $\mathrm{V}$ & III & $\mathrm{V}$ & $\mathrm{V}$ & III & $\mathrm{V}$ \\
\hline \multirow{6}{*}{$\begin{array}{l}\text { Weak neo-corporatist } \\
\text { attempts }\end{array}$} & Ireland & III & I & III & II & I & $\mathrm{V}$ \\
\hline & France & III & III & III & III & III & II \\
\hline & Greece & II & $\mathrm{V}$ & I & II & $\mathrm{V}$ & II \\
\hline & Italy & I & III & II & I & II & II \\
\hline & Portugal & IV & IV & IV & III & $\mathrm{V}$ & IV \\
\hline & Spain & II & II & III & I & III & IV \\
\hline \multirow[t]{2}{*}{ Labor exclusion } & UK & $\mathrm{V}$ & $\mathrm{V}$ & $\mathrm{V}$ & IV & $\mathrm{V}$ & IV \\
\hline & United States & $\mathrm{V}$ & $\mathrm{V}$ & n.a. & IV & $\mathrm{V}$ & n.a. \\
\hline \multirow[t]{10}{*}{ Not analyzed } & Bulgaria & I & V & I & III & $\mathrm{V}$ & I \\
\hline & Czech Republic & III & II & I & III & II & I \\
\hline & Estonia & III & III & I & III & II & III \\
\hline & Hungary & II & II & I & I & II & II \\
\hline & Latvia & II & IV & I & II & IV & II \\
\hline & Lithuania & II & IV & I & II & IV & II \\
\hline & Poland & I & IV & I & II & IV & II \\
\hline & Romania & III & $\mathrm{V}$ & I & I & IV & I \\
\hline & Slovakia & II & III & I & II & IV & II \\
\hline & Slovenia & III & III & II & III & III & II \\
\hline
\end{tabular}

SOURCE FOR INDUSTRIAL RELATIONS SYSTEM TYPES (WESTERN EUROPE): Crouch (1993:262-65).

$\mathrm{V}=>+1 S D$ (standard deviation).

$\mathrm{IV}=>0.5$ to $+1 S D$.

III $=>-0.5$ to $+0.5 S D$.

$\mathrm{II}=-1$ to $-0.5 S D$.

$\mathrm{I}=<-1 S D$.

Germany (2009 only). It is notable that Belgium and Finland have typically lower levels of both employment and debt than the others. Austria and Germany, and to a lesser extent Switzerland, form a sub-group within this category, with higher private final consumption.

Among the "unsuccessful corporatist" group, only Portugal (2000 only) succeeds in having employment levels above moderate. Only Ireland, Italy (2009 only), and Spain (2000 only) have consumption levels below moderate. In 2000, only Portugal had high debt, although by 2009 debt levels were rising in several other countries. 
Within Europe the UK is alone, but combining it with the United States as labor exclusion countries, both have a unique combination of high employment, high private consumption and high debt.

The central European group resembles the "unsuccessful corporatist" one in having a diversity of employment levels from moderate to very low. There is a thoroughly mixed pattern of consumption levels. Debt was in 2000 very low except in Slovenia, where it was low, although it had started to rise generally by the end of the decade, especially in Estonia. In general, little separates this group from the "unsuccessful corporatism'" cases.

It is surprising that the corporatism variable as at 1990 should still seem to have some relevance to grouping these countries, given that its institutions have been in decline throughout Europe since the mid-1990s. An explanation might be found in recent work by Traxler and Brandl (2009) and Traxler, Brandl, and Glassner (2008). These concentrate on the ability of different kinds of collective bargaining to deliver non-inflationary wages and to resolve dilemmas between the pursuit of productivity and that of full employment. They demonstrate the continuing, even strengthened, role of pattern bargaining based on strong exposed-sector unions (as in Austria and Germany), associated particularly with the export-strength model, and the continued capacity of systems of the Scandinavian type to deliver positive-sum agreements, even after collective bargaining as such has been considerably disaggregated. These findings suggest both a continuing viability of the corporatist concept in industrial relations, and a mixture of family similarities and differences among those based on institutional centralization and those rooted in external trade performance. We have seen traces of this in the slightly different positions of Germany and Austria vis-à-vis the Netherlands and the Scandinavian countries.

However, while this leads us to expect continuing significance in past patterns of corporatism, it is not clear precisely how these might relate to the three variables we have been studying here. Have the remains of corporatist industrial relations systems directly enabled most countries in this group to sustain high employment, or are they linked through a third variable? This might best be found by considering the link between employment and low private final consumption, which, we saw above, is to some extent related to high government final consumption. It must be remembered that this variable is not the same as high government spending, as government spending that takes the form of financial transfers to individuals (e.g., pensions, unemployment benefit) comes through as private final consumption. Government final consumption relates to provision of public services in kind. Esping-Andersen (1999) demonstrated the link between these latter and the provision of (primarily female) employment in care services, a factor that explains high employment levels in the Scandinavian countries and the Netherlands. (After 


\section{4 / Colin Crouch}

Esping-Andersen had completed his study, the UK also began to share some of these characteristics.) The link between neo-corporatist industrial relations and high spending on public services can be traced back to forms of social compromise in the mid-twentieth century that enabled working-class movements to demand both universal social services and institutionalized industrial relations, including at the political level. Are we then seeing a purely adventitious result of this earlier pattern, none of the almost entirely male instigators of which had any idea that they might be doing something for female employment? Or do industrial relations practices, social policy, and employment levels continue to reproduce themselves more actively? These questions suggest the need for further research, going beyond the broad data considered here to examine the detailed workings of the institutions concerned.

The remaining continental western European cases were having any incipient corporatism in the 1990s propped up by government encouragement. Most of these countries today, with the partial exception of Italy, have weakly established collective bargaining institutions and weak trade unions, although governments maintain a discourse of partnership and occasional social pacts, rarely practicing actual labor exclusion. It is notable that this group appears with no distinctive characteristics in the data considered here, suggesting further that there is some substance in the continuing role of the strongly characterized industrial relations and social policy institutions of most of the neocorporatist group. Ireland is a partial exception here. That country embarked on a separate and even extreme development path during the 1990s and 2000s, which took it from being among the very poorest to among the very richest countries in the Western world, albeit with extensive internal inequalities. It became highly open to direct foreign investment, while also strengthening internal corporatism in an unusual and almost contradictory combination, which did not align it to the existing neo-corporatist cases.

Ireland apart, the lack of any major differences distinguishing this group from the central European one is remarkable. These countries too, as the European Commission (2008) analysis showed, have industrial relations institutions lacking strong characteristics. In general, unions and collective bargaining are weak, although rarely is there active exclusion.

That the UK should stand alone within Europe was anticipated by Crouch's study. What could not be expected from this was the similarity between the UK (and the United States) and the neo-corporatist cases in terms of employment levels. To discuss this issue further raises the question of relative "success." Up to this point the employment level has been treated simply as a variable in a non-normative way. However, there would be a broad consensus that a capacity to provide employment constitutes a form of economic "success.' In that case, the above narrative presents two very different institutional 
patterns associated with success. One says "associated with" rather than "causing" because we do not here have evidence that enables us to attribute causal direction or even to know where the variables with which we are dealing might fit within complex causal chains. The two patterns linked with high employment are as follows: (1) relatively low private consumption, high levels of household debt, neo-corporatist industrial relations, with high levels of government final consumption and/or positive trade balances; (2) relatively high private consumption, high levels of household debt, weakly institutionalized industrial relations, with low levels of government final consumption and negative trade balances.

This conclusion has formal similarities to that of Hall and Gingerich (2004), that internally coherent if opposite institutional forms tend to perform better than intermediate, compromised cases. But this leaves three puzzles. First, as already noted, it is not clear exactly how the industrial relations system fits into the new neo-corporatist pattern. Second, in what senses do the "unsuccessful" cases, primarily those of southern and central Europe, constitute intermediate cases, as the latter in particular are not necessarily associated with compromises between rival models? In most respects, they resemble the Anglo-American cases, with relatively high private consumption, weakly institutionalized industrial relations, low levels of government final consumption, and negative trade balances. They differ only in the size of household debt. Third, this last point raises the issue of the role of household debt in the neocorporatist cases. While the Anglophone countries combine high debt and high private consumption, in the neo-corporatist ones debt seems to have nothing to do with private consumption.

\section{The Puzzle of Household Debt}

The hypotheses at the outset of this article anticipated that the UK and the United States, seen as the countries that personified the move into high levels of household debt as ways in which personal consumption was sustained in uncertain labor markets, would have the highest levels of such debt. But our data have shown that the highest levels of debt of all are found in the neo-corporatist countries of northwest Europe, all of which paradoxically have distinctly low proportions of personal final consumption spending. One might have expected these countries to have high employment sustained by high government final consumption, while in the UK and the United States it was sustained by high personal debt. Instead, in the former group high employment seems to be related to both. The second hypothesis proposed at the outset of this article is refuted. 


\section{6 / Colin Crouch}

These three-way comparisons among the neo-corporatist, the Anglo-American, and the remaining European cases lead us to suspect that household debt plays a different role in different economies. We know that in general higherincome households are far more likely than the lower ones to maintain high levels of debt. This partly accounts for the differences among our groups of countries, as the northern European and Anglo-American countries have higher numbers of wealthy people within their populations. But this fact about the distribution of debt means that further research on the implications of debt for macro-economic behavior requires micro-level research on who bears debt, and the purposes for which they use it. In general, we should expect poorer people to use debt for everyday consumption purposes, while wealthier people will use it for capital purchases. If high debt levels are associated with relatively low private consumption shares in some countries but high shares in others, we might expect that in the latter cases debt will be more widespread and not confined to wealthy groups only. This would rehabilitate the rejected hypothesis.

Unfortunately, there are not many comparable studies of this issue, interest in household debt having developed only in very recent years as its levels soared. The OECD has carried out one study that covers a small number of the countries that have been studied here. While the number is small, the regional coverage is good, with the exception of an absence of any material on central Europe (OECD 2006). It is interesting that the issue was exercising the OECD 2 years before the crisis broke. On the basis of the initial assumptions of this article, we would expect it to be only in the UK and the United States that private debt was widespread among poorer proportions of the population. Table 8 presents data relevant to testing this hypothesis. The figures

TABLE 8

Debt Burdens for Lower-Income Groups, Various Countries, Mid-2000s

\begin{tabular}{|c|c|c|c|c|}
\hline \multirow[b]{2}{*}{ Percentiles of income distribution } & \multicolumn{2}{|c|}{ Percentage with debt } & \multicolumn{2}{|c|}{$\begin{array}{l}\text { Median debt as } \\
\text { percentage of } \\
\text { per capita income }\end{array}$} \\
\hline & $<20$ & $21-40$ & $<20$ & $21-40$ \\
\hline Finland & 29 & 40 & 34 & 96 \\
\hline Germany & 17 & 29 & 430 & 430 \\
\hline Italy & 9 & 19 & 44 & 57 \\
\hline The Netherlands & 31 & 42 & 208 & 542 \\
\hline Spain & 16 & 38 & 93 & 107 \\
\hline Sweden & 19 & 45 & 99 & 99 \\
\hline UK & 31 & 49 & 38 & 30 \\
\hline United States & 52 & 70 & 24 & 54 \\
\hline
\end{tabular}

SOURCE: OECD (2006:147-48). 
relate to the mid-2000s, in the final years of pre-crisis lending activity. Columns 2 and 3 show the percentages of households in the four lowest deciles of the income distribution who hold debt. Our hypothesis leads us to expect this to be higher in the UK and the United States than elsewhere, including in the high-debt, low private consumption countries. This is confirmed. However, the differences between the UK and the Netherlands, and for the third and fourth deciles for Sweden, are not strong. Columns 4 and 5 examine the size of the debts being carried by these lower-income groups. Again, we would expect these shares to be higher in the UK and the United States. However, the really serious burdens are seen to be those of lower-income Germans and Dutch. In fact, the British and U.S. figures are the lowest. The available evidence on who bears debt is inconclusive.

The Danish government has argued (Denmark, Ministry of Finance 2009) that Eurostat's published household debt statistics are misleading, as they report debt as a proportion of disposable income, that is, including government transfer payments but net of taxes. It points out that in Denmark (and, one can add, the other Scandinavian countries and the Netherlands) households receive an important part of their income in the form of public services in kind, for which they pay high taxes. This exaggerates the burden of debt on poorer Danish families when compared with a country like the United States, where taxes are lower and therefore disposable income higher, but where much less is provided as public services at zero or subsidized cost. Since government final consumption expenditure is closely related to this element, it means that debt will appear higher in countries where this is high. In addition to possibly accounting for high debt in these countries, this also suggests that our variables of private final consumption and household debt are not statistically independent of each other. Table 9 therefore recalculates the debt statistics for 2008, adjusting for size of government final consumption expenditure, and indicates the distribution of countries around standard deviations as before. Little difference is in fact made to countries' relative positions. The only change relevant to our consideration of the neo-corporatist group concerns a drop in Sweden's relative position. This leaves Denmark and the Netherlands in particular with high levels of debt exposure for lower-income households.

It remains possible that other factors are involved. For example, are lowincome northern Europeans using their loans only to fund house purchases, while British and U.S. citizens are using theirs for consumption? More research is needed, but we can gain some macro-level indications by looking at the spread of short-term debt. This will not tell us to what extent the holders of sub-prime mortgages use mortgage extensions to finance consumption, but it should access other uses of debt, such as credit cards, for consumption rather than investment purposes. OECD statistics define short-term debt as debts that are scheduled for 
TABLE 9

Household Debt Adjusted for Levels of Government Final Consumption

\begin{tabular}{lcc}
\hline \hline & $\begin{array}{c}\text { Adjusted household } \\
\text { debt ratios }\end{array}$ & Groups \\
\hline Austria & 68.74 & III \\
Belgium & 63.57 & II \\
Bulgaria & 39.93 & II \\
Czech Republic & 30.43 & I \\
Denmark & 204.87 & V \\
Estonia & 74.72 & III \\
Finland & 78.31 & III \\
France & 60.42 & III \\
Germany & 74.72 & III \\
Greece & 59.41 & III \\
Hungary & 50.86 & II \\
Ireland & 165.01 & V \\
Italy & 46.52 & II \\
Latvia & 60.45 & III \\
Lithuania & 37.45 & II \\
The Netherlands & 177.80 & V \\
Norway & 147.35 & V \\
Poland & 41.78 & II \\
Portugal & 109.84 & IV \\
Romania & 27.81 & I \\
Slovakia & 38.76 & II \\
Slovenia & 34.46 & II \\
Spain & 105.46 & III \\
Sweden & 107.45 & III \\
Switzerland & 152.41 & V \\
UK & 123.58 & IV \\
\hline Sori Owa & & \\
\hline
\end{tabular}

SourCE: Own calculations based on Eurostat statistical database and OECD National Income Accounts.

$\mathrm{V}=>+1 S D$ (standard deviation).

$\mathrm{IV}=>0.5$ to $+1 S D$.

III $=>-0.5$ to $+0.5 S D$.

II $=-1$ to $-0.5 S D$.

$\mathrm{I}=<-1 S D$.

resolution within 12 months. Table 10 presents the size of this debt per country for those countries where the OECD had data, expressed as a percentage of GDP, in 2000 or 2001 and 2008 or 2009 . We should hypothesize that these debt levels should be highest in the Anglophone countries.

At the earlier date, the Anglophone group-Ireland, the UK, and the United States-did indeed occupy the top three places in this league table, with levels considerably higher than all other countries, except perhaps Greece. Unfortunately, there are no data for Denmark, but the other members of the "Scandinavia plus Netherlands" group had lower levels. By 2009, the UK and the United States had seen short-term household debt reach even higher proportions of GDP, but Irish levels had declined. Greece was now the third highest, 
TABLE 10

Short-Term Debt as Percentage of Gross Domestic Product, 2000/2001 and 2008/2009

\begin{tabular}{lcr}
\hline \hline & 2000 & 2009 \\
\hline Austria & 5.66 & 6.77 \\
Belgium & 2.75 & 1.87 \\
Czech Republic & 0.58 & 3.02 \\
Denmark & - & 10.29 \\
Estonia & 0.16 & 1.68 \\
Finland & - & 3.56 \\
France & 2.07 & 2.12 \\
Germany & 5.51 & 3.49 \\
Greece & 3.53 & 10.80 \\
Hungary & 0.89 & 6.50 \\
Ireland & 11.32 & 5.28 \\
Italy & 4.64 & 4.96 \\
The Netherlands & 3.36 & 5.16 \\
Norway & 2.90 & 4.94 \\
Poland & 2.39 & 4.99 \\
Portugal & 1.05 & 6.09 \\
Slovakia & 2.07 & 7.30 \\
Slovenia & 3.26 & 5.99 \\
Spain & 3.21 & 4.95 \\
Sweden & 0.00 & 0.01 \\
UK & 10.76 & 16.14 \\
United States & 19.33 & 22.37 \\
\hline Nor: & &
\end{tabular}

Note: $-=$ no data.

SOURCE: Own calculations based on OECD data.

but Denmark ranks fourth, with a considerably lower level than the UK and the United States but distinctly higher than elsewhere.

\section{Conclusion}

Initial expectations that there would be a difference between Anglo-American economies with high household debt, high private consumption, and high employment, levels and continental European ones with low debt, low consumption, and low employment were only partly confirmed. High employment levels have been, without exception, associated with high household debt, but there have been two very different patterns of private consumption: low levels in most (not all) of the European countries that have in the past featured some form of successfully established neo-corporatist industrial relations; high levels in the UK and the United States, countries with strong tendencies toward the political exclusion of organized labor. Here too there is perhaps more use of household debt to sustain consumption. There is, in more recent years, a 


\section{0 / Colin Crouch}

potential sub-group among the neo-corporatists (Austria and Germany) of countries with fairly high employment and moderate levels of both consumption and debt, but apart from that it is difficult to discern patterns among the large remaining group of continental European cases. It is also difficult to distinguish between the performances on the variables considered here of southwestern and former state-socialist European countries.

There are clearly severe limits to how far one can draw conclusions based on aggregate data. Consumption and household debt are distributed very unequally among populations, and micro-level and individual data are needed to draw more detailed conclusions about the way debt is being used in different societies. It does, however, seem likely that the neo-corporatist countries with high levels of government rather than private consumption have found only a partial answer to the problem of sustaining employment in a period of globalization.

Esping-Andersen (1999) had argued that there could be two successful approaches to providing services employment that would replace the industrial jobs being lost by the existing wealthy countries to other parts of the world: growth in public-service jobs, particularly in the care sector, associated with the Scandinavian countries; and growth in low-productivity private services to households, provided income inequalities were sufficiently great to enable wealthy households to buy the services of low-income persons. He associated this with the Anglo-American type of economy. (In practice, the UK has been something of a hybrid between the Scandinavian and American types, with higher spending on public services than the United States.) He could not have anticipated the role that was to be played in sustaining consumption by household debt. In the Anglo-American type of economy, this has probably enabled a far wider range of the population than he envisaged sharing in high consumption spending, their relatively static and often insecure incomes being reinforced by loans. Exactly what role has been played by household debt in sustaining the Scandinavian countries and the Netherlands requires much more research to determine. Is it, for example, relevant that the two countries with the highest debt levels have been Denmark and the Netherlands, the two northwest European countries that are considered to have gone furthest in deregulating their labor markets and establishing "flexicurity" (Jørgensen and Madsen 2007; Muffels, Wilthagen, and van den Heuvel 2002, 2008; Muffels et al. 2008; Wilthagen and Tros 2004). Their success in achieving high levels of employment with reduced formal labor security is usually attributed to the existence of extensive welfare-state safeguards. But has household debt also played a part? It is notable that a country outside Europe that also has exceptionally high household debt, New Zealand, also undertook a major labor deregulation exercise. 
More work is also needed on how different types of industrial relations and collective bargaining are operating today, and whether the role of certain types in wage restraint observed by Traxler and Brandl can be related to these patterns of employment, consumption, and debt.

We have concentrated here on the countries with strong profiles on the variables that we have chosen to study. This has left the majority of European countries relatively neglected. The ostensible similarities between many countries in western and central Europe are probably misleading, as production is shifting from west to east, producing different occupational structures in the two zones despite aggregate employment levels that are not dissimilar. What variables need to be added to the comparison to bring out these differences, and what is the role of differences in industrial relations systems in establishing an analytical scheme?

Finally, it must be remembered that the discussion hitherto has examined its cases at two different and unstable moments, although closely related in time: the beginning of the twenty-first century, when the financial system that made possible the rise in household debt was in the ascendancy; and a decade later, when that system was collapsing. Future research will need to examine what came next, following a period of major retrenchment in both private and public debts.

\section{REFERENCES}

Amable, Bruno. 2003. The Diversity of Modern Capitalism. Oxford: Oxford University Press.

Bellofiore, Roberto, and Joseph Halevi. 2012. 'Deconstructing Labor. A Marxian-Kaleckian Perspective on What is 'New' in Contemporary Capitalism and Economic." In Employment, Growth and Development. A Post-Keynesian Approach, edited by Claude Gnos and Louis-Philippe Rochon. Cheltenham, UK: Elgar.

Crouch, Colin. 1993. Industrial Relations and European State Traditions. Oxford: Oxford University Press.

. 1996. "Revised Diversity: From the Neo-Liberal Decade to Beyond Maastricht." In Industrial Relations in Europe. Traditions and Transitions, edited by E. Van Ruysseveldt and J. J. Visser, pp. 358-75. London: Sage.

—. 2009. "Privatized Keynesianism: An Unacknowledged Policy Regime." British Journal of Politics and International Relations 11: 382-99.

— Diversity. London: Sage.

Denmark, Ministry of Finance. 2009. “Danish Households' Net Wealth Position.” http://www.fm.dk/Publikationer/Arbejdspapirer/2009/ /media/Files/Arbejdspapirer/Household\%20wealth\%20position.ashx (accessed May 20, 2009).

Ebbinghaus, Bernhard, and Jelle Visser. 1997. "Der Wandel der Arbeitsbeziehungen im westearopäischen Vergleich.' In Die westearopäischen Gesellschaften im Vergleich, edited by S. Hradil, and S. Immerfall, pp. 333-76. Opladen: Leske + Budrich.

Esping-Andersen, Gøsta. 1990. The Three Worlds of Welfare Capitalism. Cambridge: Polity Press.

. 1999. Social Foundations of Postindustrial Economies. Oxford: Oxford University Press.

European Commission. 2008. Industrial Relations in Europe. Luxemburg: Official Publication Office of the European Communities. 


\section{2 / Colin Crouch}

Hall, Peter A., and Daniel W. Gingerich. 2004. "Varieties of Capitalism and Institutional Complementarities in the Macroeconomy: An Empirical Analysis." MPIfG Discussion Paper 04/5. Cologne: MPIfG. , and David Soskice (Eds.). 2001. Varieties of Capitalism. Oxford: Oxford University Press.

Jørgensen, Henning, and Per K. Madsen. (eds). 2007. Flexicurity and Beyond: Finding a New Agenda for the European Social Model, pp. 365-91. Copenhagen: DJØF Publishing.

Kohl, Henning, and Hans-Wolfgang Platzner. 2007. "The Role of the State in Central and East European Industrial Relations: The Case of Minimum Wages." Industrial Relations Journal 38(6): 614-35.

Muffels, Ruud, Ton Wilthagen, and Nick van den Heuvel. (2002). "Labour Market Transitions and Employment Regimes: Evidence on the Flexicurity-Security Nexus in Transitional Labour Markets." WZB Discussion Paper FS I 02-204. Berlin: Wissenschaftszentrum Berlin für Sozialforschung. in Transition. Cheltenham, UK: Edward Elgar.

, Ute Klammer, and Ton Wilthagen. 2008. Flexibility and Security over the Life Course. Dublin: European Foundation for the Improvement of Working and Living Conditions.

OECD. 2006. OECD Economic Outlook. Paris: OECD.

OECD. 2008. OECD Economic Outlook. Paris: OECD.

Panitch, Leo, and Martijn Konings. 2009. "Myths of Neoliberal Deregulation." New Left Review 57: 67-83.

Schmidt, Vivian A. 2002. The Futures of European Capitalism. Oxford: Oxford University Press. 2006. Democracy in Europe. Oxford: Oxford University Press.

Traxler, Franz, and Bernd Brandl. 2009. "Towards Europeanization of Wage Policy: Germany and the Nordic countries." European Union Politics 10: 2.

and Evidence." British Journal of Industrial Relations 46(1): 33-58.

Wade, Robert. 2008. "Financial Regime Change?" New Left Review 53: 5-21.

Wilthagen, Ton, and Frank H. Tros. 2004. “The Concept of 'Flexicurity': A New Approach to Regulating Employment and Labour Markets' in 'Flexicurity: Conceptual Issues and Political Implementation in Europe."' Transfer 10: 2. 
Copyright of Industrial Relations is the property of Wiley-Blackwell and its content may not be copied or emailed to multiple sites or posted to a listserv without the copyright holder's express written permission. However, users may print, download, or email articles for individual use. 